5. Ly`pchuk O. Stan dotry`mannya ta zaxy`st prav etnonacional’ny`x menshy`n v Ukrayini. Politologichni zapy`sky`. 2012. \# 6. URL: http://nbuv.gov.ua/UJRN/Polzap_2012_6_18. (data zvernennya: 11.05.2019)

6. Mel`ny`k G., Guby`cz`ky`j L. Zaxy`st prav nacional`ny`x menshy`n u Respublici Pol`shha: analiz zakonodavstva. 2017. 150 s. URL: http://elibrary.kubg.edu.ua/id/eprint/19759/1/G_Melnik_Konf_07_04_2017_FPMV.pdf (data zvernennya: 11.05.2019).

7. Fedun` O., Papish N. Polity`ko-pravovi aspekty`zaxy`stu prav nacional`ny`x menshy`n v Ukrayini. $2016.60 \mathrm{~s}$. URL: http://intrel.lnu.edu.ua/wp-content/uploads/2015/09/72-98-1-SM.pdf (data zvernennya: 07.05.2019).

8. Shy`pka N. Legity`maciya polity`chnoyi sub'yektnosti nacional`ny`x menshy`n v Ukrayini. Vijs`kovonaukovy`j visny'k. 2008. Vy`p. 10. URL: http://nbuv.gov.ua/j-pdf/vnv_2008_10_20.pdf (data zvernennya: 12.05.2019).

9. Barwinski M. Pojecie narodu oraz mniejszosci narodowej I etnicznej w kontekscie geograficznym, politycznym i socjologicznym. 2004. 73 s. URL: http://dspace.uni.lodz.pl/xmlui/bitstream/handle/11089/3788/Barwi\%C5\%84ski_Folia\% 20Geographica_2004.pdf?sequence=1\&isAllowed=y (data zvernennya: 18.05.2019).

10. Idzik I., Nitka J., Marcinowska H., Onuchowska A., Kasprzyk T. Program edukacyjny Równi- Rózni. Podrecznik dla prowadzacych lekcje na temat mniejszosci narodowych i etnicznych. 2004. № $1.70 \mathrm{~s}$.

11. Janusz G., Bajda P. Prawa mniejszości narodowych. Standardy europejskie. Warszawa, 2000. 34 s.

12. Ministerstwo Spraw Zagranicznych. Definicje, pojęcia dotyczące spraw polonijnych. od 2016-12-11. URL: https://msz.gov.pl/pl/polityka_zagraniczna/polonia/definicje_pojecia/(data zvernennya: 14.05.2019).

13. Organek L. Charakter i położenie mniejszości ukraińskiej w Polsce. 2016. URL: http://eprints.zu.edu.ua/21627/ (data zvernennya: 11.05.2019).

14. Piąty raport dotyczący sytuacji mniejszości narodowych i etnicznych oraz języka regionalnego w Rzeczypospolitej Polskiej. Warszawa, 2015. URL: http://mniejszosci.narodowe.mswia.gov.pl/download/86/19700/ VRaportUstawowy.pdf (data zvernennya: 14.05.2019).

DOI 10.31558/2617-0248.2019.4.12

УДК 351.77:351.84

\title{
ПОЛІТИКО-ПРАВОВІ ПРОБЛЕМИ НАДАННЯ ПАЛІАТИВНОЇ ДОПОМОГИ ІНКУРАБЕЛЬНИМ ХВОРИМ В УКРАЇНІ
}

\author{
ORCID ID: https://orcid.org/0000-0001-5825-3631 \\ Калашлінська М. В., к. політ. н., Одеса (Україна)
}

Стаття присвячена розгляду політико-правових проблем надання паліативної та хоспісної допомоги інкурабельним хворим в Україні. Автором були розглянуті основні поняття в цій сфері («інкурабельний хворий», «паліативна допомога», «хоспіс», «паліативна політика»), зроблений огляд нормативноправової бази, яка регулює цю сферу в Україні. Кожна людина сподіваються на добру смерть, чи, якщо бути точнішими, на "добре життя до самого кінця». На жаль, це відбувається не з кожним. Багато людей змушені проходити в кінці свого життя через біль та страждання. Мета паліативної допомоги полягає в запобіганні стражданню та полегшені стану пацієнта, який страждає невиліковною хворобою - шляхом активного медичного втручання з метою зняття больових синдромів, та наданням адекватного лікування, яке дозволить збалансувати ці синдроми протягом доби. На жаль, Україна є країною з низьким індексом «якості смерті», через відсутність політичної волі, недосконалість законодавчої та нормативно-правової бази, практичну відсутність фінансування, а також інформаційне замовчування цієї теми. Всі ці фактори створюють ситуацію, коли тисячі громадян України щодня потерпають від страждань, не отримуючи належної паліативної допомоги, що призводить до порушення реалізації їх конституційних прав на охорону здоров'я, життя, честь і гідність, а також підриву довіри суспільства до політичної влади в країні, яка вважає таку ситуацію «нормальною». Паліативна допомога спрямована, перш за все, на ослаблення болю та болісних симптомів, а також включає в себе соціальну, психологічну і моральну підтримку, що надає можливість хворому зберегти максимально повноцінне та активне життя до останнього ії дня. Крім того, вона включає в себе систему підтримки для близьких хворого, щоб також допомогти їм справитися з його втратою, коли це відбудеться. В статті наголошується, що тематика паліативної та хоспісної допомоги, як правило, ігнорується науковцями політологами та $є$ недостатньо дослідженою ними. Також в роботі окреслені основні напрями, в яких, на нашу думку, має розвиватися паліативна політика України на сучасному етапі її розвитку.

Ключові слова: інкурабельний пацієнт, якість життя, індекс якості смерті, паліатив, паліативна допомога, хоспіс, паліативна політика.

Kalashlinska Maryna Victorivna, The legal and political problems of hospice care for patients with incurable disease in Ukraine

The article deals with the political and legal problems of palliative and hospice care for incurable patients in Ukraine. The author considered the basic concepts in this area («incurable patient», "palliative care», 
«hospice», «palliative policy»), analyzed the legal framework for hospice care in Ukraine. The author notes that all people hope for a good death, or rather, «a good life to the very end». Unfortunately, this doesn't happen to everyone. Many people have to be in pain and suffering at the end of their lives. The goal of the palliative care is to prevent suffering and to alleviate the condition of the patient suffering from an incurable disease - by active identification of syndromes, like pain, and by providing adequate treatment that will balance the syndromes as much as possible during day and night. Public engagement and policy interventionsto improve the quality of death through the provision of high quality palliative care have gained momentum in recent years, and some countries have made greatstridesin improving affordable accessto palliative care. Unfortunately, Ukraine is a country with a low index of "quality of death», due to lack of political will, imperfection of legislative and regulatory framework, practical lack of funding, as well as informational silence on this topic. So thousands of Ukrainian's citizens today do not receive any palliative care in the end of their lives. This situation is violates their constitutional rights to health, life, honor and dignity. Palliative care is aimed primarily at alleviating pain and painful symptoms, and includes social, psychological and moral support that enables the patient to maintain the most fulfilling and active life until her last day. In addition, it includes a support system for near patient to help them cope with the loss when it will happen.

Key words: incurable patient, quality of life, quality of death index, palliative care, hospice, hospice care, palliative policy.

Постановка проблеми. Для вивчення політико-правових проблем надання паліативної допомоги інкурабельним хворим в Україні нам необхідно визначити поняття «інкурабельний хворий», «паліативна допомога», «хоспіс», та зрозуміти місце, яке відведено цьому напряму в паліативній політиці української держави. Для цього важливо окреслити ситуацію, що існує на теперішній момент в Україні щодо допомоги невиліковним пацієнтам в останній період їхнього життя, порівняти з тими потребами суспільства, що існують в цій сфері, а також з'ясувати основні вектори подальшого розвитку української паліативної політики.

Стан дослідження. Сфера наукових досліджень сфери паліативної допомоги в Україні вивчалася, зокрема, такими науковцями, як К. Аймедов, Л. Білик, Г. Бондар, Ю. Вороненко, Ю. Губський, К. Данилюк, Д. Дячук, К. Данилюк, Ж. Золотарьова, С. Крюков, І. Кужель, С. Москвяк, С. Прокіп, В. Шатило. Але кількість таких досліджень в Україні, на жаль, $\epsilon$ незначною, а також основний акцент в цих дослідження часто робиться на медичній складовій проблеми. Загалом, ми можемо констатувати, що до теперішнього часу проблематика паліативної політики України є недостатньо вивченою та потребує подальших грунтовних досліджень.

Метою статті $є$ оцінка стану надання паліативної допомоги інкурабельним хворим в Україні та аналіз основних політико-правових проблем в цій сфері.

Виклад основного матеріалу. Найфундаментальнішим питанням людського буття у всі часи була проблема життя та смерті. Навколо цієї дихотомії обертаються філософські та релігійні пошуки, а також точаться дискусії науковців й пересічних громадян. Важко уявити сферу, яка би містила в собі стільки ж табу та забобон, адже кожна людина, що народжується, має головну спільну рису з усіма іншими - термін життя кожного з нас є обмеженим, але конкретний строк, що відмірений кожній людині, як правило, залишається таємницею. I тут кожному залишається сподіватися, що йому судилося померти в глибокій старості без мук та страждань, але, на жаль, такий щасливий кінець чекає далеко не кожного. Проблема, яка буде розглядатися в цій статті стосується саме тих осіб, яким не пощастило, а саме хворих, що визнані інкурабельними, і не пощастило їм щонайменше двічі, оскільки такий вирок їм було винесено в Україні.

Термін «інкурабельний» походить від латинського слова «incurabilis», що перекладається як «невиліковний». Не вдаючись до суто медичної специфіки, зазначимо, що цим терміном позначається пацієнт, який через наявність в його організмі патологічного процесу або загальних порушень, не може бути вилікуваний сучасною медициною, та прогноз життя якого є дуже обмеженим (як правило, від декількох тижнів до кількох місяців).

Право людини на всебічну медичну допомогу в кінці iï життя на перший погляд здається очевидним та таким, що не потребує доказування. Але саме очевидні речі деколи доводиться доводити найбільше. Ні в кого зараз не викликає здивування, що момент приходу в світ людини має бути захищений та підтриманий медициною. Загальнозрозумілим є також і питання, що медична допомога має супроводжувати людину протягом всього ііі життя. Так само природним здається максимальне забезпечення з боку держави медичної підтримки для людині, чиє життя закінчується (при чому, далеко не завжди це особа похилого віку, часто такими пацієнтами стають достатньо молоді люди i, навіть, діти). Але в українській практиці все виявляється не зовсім так.

Зазначимо, що останні дні та місяці життя таких осіб, як правило, супроводжуються важкими болями, пов'язаними з прогресуванням основного захворювання, а самі хворі стають повністю залежними від того догляду, який їм може забезпечити їх оточення. Безсумнівно, що багато хто з цих хворих потребує знаходження в умовах стаціонарного догляду. Однак традиційні стаціонари в Україні намагаються не приймати на себе турботу про цих пацієнтів, саме через те, що ті не мають шансу бути вилікувані. I фраза про таких хворих: «Виписали додому помирати», на жаль, залишається традиційною в сучасній українській медицині XXI століття.

Розглянемо поняття «паліативна допомога» більш детально. За визначенням, яке було надано Всесвітньою організацією охорони здоров'я в 2002 році, паліативна допомога - це ... «... підхід, що дозволяє поліпшити якість життя пацієнтів та членів їх сімей, які зіткнулися з проблемою смертельного захворювання, шляхом запобігання та полегшення страждань завдяки ранньому виявленню і точній оцінці проблем, що виникають, і проведенню адекватних лікувальних заходів (при больовому синдромі та інших розладах життєдіяльності), а також надання психосоціальної і моральної підтримки» [3]. 
Варто чітко розуміти ту прірву, що полягає між ідеєю паліативної допомоги та, наприклад, евтаназії. Паліативна допомога стверджує цінність якісного життя до його останньої секунди та, визнаючи смерть як природну подію, не прагне ані прискорити, ані відтягнути їі настання. Головна ідея тут полягає в формулі: «Якщо людину не можна вилікувати, це не означає, що їй не можна допомогти».

Паліативна допомога спрямована, перш за все, на ослаблення болю та болісних симптомів, а також включає в себе соціальну, психологічну і моральну підтримку, що надає можливість хворому зберегти максимально повноцінне та активне життя до останнього іiі дня. Крім того, вона включає в себе систему підтримки для близьких хворого, щоб також допомогти їм справитися з його втратою, коли це відбудеться.

Вважаємо доречним навести визначення К. Аймедова, який розглядає паліативну допомогу як комплексний підхід, мета якого забезпечити максимальну якість життя пацієнта 3 невиліковним (смертельним) захворюванням і членів його родини шляхом запобігання та полегшення страждань завдяки ранньому виявленню i точному діагностуванню (оцінці) проблем, що виникають та проведення адекватних лікувальних заходів (при больовому синдромі та інших розладах життєдіяльності), а також надання психосоціальної та моральної підтримки. Цей підхід включає забезпечення адекватного знеболення пацієнта. При цьому біль він розглядається як комплексне фізичне, соціальне, психологічне, духовне страждання, отже і в межах паліативної допомоги також виділяє медичний соціальний, психологічний та духовний компонент.

За експертними даними [2, с. 9] в Україні безпосередньої паліативної допомоги потребують щонайменше півмільйона осіб в рік, а з врахуванням членів їх сімей ця цифра зростає мінімум до 1,5 мільйонів осіб. Серед яких, за інформацією Дитячого фонду ООН (ЮНІСЕФ), від 39 до 70 тис. дітей. При цьому в країні також не існує спеціальної державної програми надання належної допомоги для таких дітей та їх батьків. Адже батьки та члени сімей таких пацієнтів також потребують професійної допомоги, оскільки з'явлення в родині невиліковно хворої людини спричиняє критичне зниження якості життя всієї родини, як в економічному, так і в соціальному й психоемоційному відношенні.

На жаль, українська законодавча база щодо надання паліативної допомоги населенню $є$ розрізненою, оскільки в нашій державі відсутній єдиний Закон про паліативну допомогу, тож регулювання цієї сфери здійснюється переважно на рівні підзаконних актів.

Звичайно, фундаментальні права людини на життя, гідність, медичну допомогу тощо містяться безпосередньо в Конституції України [4], але згадок про право на паліативну допомогу там не міститься. Законодавча вказівка на паліативну сферу міститься в Основах законодавства України про охорону здоров'я [7], у ст. 33 яких визначено паліативну допомогу як окремий вид медичної допомоги поряд з екстреною, первинною, вторинною (спеціалізованою), третинною (високоспеціалізованою) та медичною реабілітацією. Також у ст. 354 цього Закону зазначено, що на останніх стадіях перебігу невиліковних захворювань пацієнтам надається паліативна допомога, яка включає комплекс заходів, спрямованих на полегшення фізичних та емоційних страждань пацієнтів, а також надання психосоціальної і моральної підтримки членам їх сімей. Важливим є положення, що паліативна допомога надається безоплатно за направленням закладу охорони здоров'я, у якому пацієнту надавалася вторинна (спеціалізована) чи третинна (високоспеціалізована) медична допомога, із яким укладено договір про медичне обслуговування населення. Після цих положень зазначається, що сам порядок надання паліативної допомоги та перелік медичних показань для іiі надання визначаються центральним органом виконавчої влади, що забезпечує формування державної політики у сфері охорони здоров'я.

Таким чином, подальше регулювання цієї сфери відбувається вже на рівні МОЗ України, зокрема, в п. 1.4 Наказу Про організацію паліативної допомоги в Україні № 41 від 21.01.2013 року [6] визначаються наступні поняття:

- загальна паліативна допомога - паліативна допомога, яка надається паліативному пацієнту від моменту встановлення діагнозу невиліковного прогресуючого захворювання медичними працівниками відповідно до їх спеціалізації;

- паліативна допомога - вид медичної допомоги, який дає змогу покращити якість життя паліативного пацієнта та допомогти членам його родини шляхом профілактики та полегшення страждань невиліковно хворої людини;

- паліативне лікування - складова паліативної допомоги, яка включає надання адекватного ефективного знеболювання, медикаментозної терапії, медико-психологічної реабілітації, хірургічних та інших методів лікування, догляду;

- спеціалізована паліативна допомога - паліативна допомога, яка надається пацієнту зі складними потребами, що не можуть бути адекватно вирішені на первинному рівні надання медичної допомоги.

Пункти 3.1 та 3.2 цього Наказу також зазначають, що паліативна допомога надається безоплатно за направленням закладу охорони здоров'я, а форми надання паліативної допомоги у стаціонарних, амбулаторних умовах або вдома визначаються залежно від стану пацієнта та його родини.

Цим Наказом також затверджено Порядок надання паліативної допомоги і Перелік медичних показань для надання паліативної допомоги.

Крім вказаного Наказу МО3, в Україні існує Державний стандарт паліативного догляду затверджений Наказом Міністерства соціальної політики України № 58 від 29.01.2016 року [5]. У вказаному стандарті зазначається, що паліативним (хоспісним) доглядом є допомога в самообслуговуванні, спостереження за станом здоров'я, сприяння наданню медичних послуг, допомога у забезпеченні технічними засобами реабілітації, навчання навичкам користування ними, навчання членів сім’ї догляду, представництво інтересів, психологічна підтримка особи та членів іiі сім’ї, надання інформації з питань соціального захисту населення, допомога в отриманні 
безоплатної правової допомоги, організація та підтримка груп самодопомоги. Згідно цього Наказу отримувачем соціальної послуги з паліативного догляду виступає особа з обмеженим прогнозом життя, яка має невиліковні прогресуючі захворювання, що супроводжуються вираженим больовим синдромом, тяжкими розладами життєдіяльності, потребує догляду, психологічної, соціальної, духовної підтримки, користується заходами, які становлять зміст соціальної послуги з паліативного догляду. Вказується, що паліативну допомогу повинно надавати мультидисциплінарна команда, що включає не менше трьох спеціалістів, серед яких: соціальний працівник, медичний працівник, юрисконсульт, психолог, духівник та інші фахівці, що пройшли навчання за тематичними циклами з питань паліативного догляду.

Надання паліативної допомоги в Україні також регулюється й іншими нормативно-правовими актами. Наприклад: Уніфікованим клінічним протоколом паліативної медичної допомоги при хронічному больовому синдромі, який був затверджений Наказом МО3 України № 311 від 25.04.2012 р.; Наказ МО3 України № 494 від 07.08.2015 р. Про деякі питання придбання, перевезення, зберігання, відпуску, використання та знищення наркотичних засобів, психотропних речовин і прекурсорів узакладах охорони здоров'я; спільний Наказ Міністерства соціальної політики та Міністерства охорони здоров’я України № 317/353 від 23.05.2014 р. Про затвердження Порядку взаємодії суб'єктів при наданні соціальних послуг паліативного догляду вдома невиліковно хворим [9].

Як бачимо, законодавчо питання паліативної допомоги не ігнорується в українській нормативно-правовій сфері, але складається парадоксальна ситуація, коли право пацієнта на паліативну допомогу, з одного боку, визнано українським законодавством (недосконало, але визнано), а, з другого боку, практичний доступ до паліативної допомоги залишається скоріше декларативним, ніж реальним.

На підтвердження цієї тези зазначимо, що Згідно з класифікацією Міжнародного альянсу паліативної допомоги, що діє при ВООЗ, Україна належить до групи країн «3 несистемним забезпеченням паліативної допомоги» [8]. Такий самий статус отримали Вірменія, Куба, Сгипет, Пакистан, РФ та ще кілька держав, які об'єднує відсутність підтримки паліативного руху, дефіцит знеболювальних засобів (зокрема морфіну) та мала кількість хоспісних і паліативних центрів.

Також тут необхідно згадати про фундаментальні дослідження, які були проведені британським журналом The Economist, де були проаналізовані якість догляду за людьми похилого віку та інкурабельними пацієнтами в завершальний період їх життя в різних країнах світу. На підставі цих досліджень був сформований документ The Quality of Death Index [1], в якому проведено ранжування «якості смерті» в різних країнах. Методологія дослідження грунтувалася на комбінованому використанні експертного оцінювання та статистичного аналізу стану двадцяти чотирьох якісних та кількісних показників, які можна об'єднати в чотири основні групи:

1. наявність системи базових соціальних та медичних послуг для людей, що знаходяться в кінці життя;

2. доступність цих послуг;

3. вартість послуг;

4. якість послуг.

За усіма цими показниками, відповідно до результатів цього дослідження в 2015 році, Україна знаходилася на 69 (!) місці серед 80 країн світу, що були розглянуті досліджені (гірше тільки в Ефіопії, Нігерії, Іраці, Ірані, Ботсвані тощо), отримавши 25,5 зі 100 можливих балів (в Ефіопії, наприклад, 25,1). Серед європейських країн за цими показниками Україна знаходилася на останньому місці.

Тож, через практичну відсутність в Україні системи паліативної допомоги люди в термінальній (пограничній, кінцевій) стадії захворювання залишаються сам на сам зі своїми проблемами: страждання через розлади систем життєдіяльності, нестерпний біль, відсутність необхідного догляду і психологічної підтримки, самотність та соціальну ізоляцію [2, с. 8]. При цьому міжнародні організації та фонди одностайно стверджують про недотримання в Україні елементарного права на знеболення [10]. Відсутність в нашій державі системної організації допомоги інкурабельним хворим та їх близьким все частіше обумовлює перехід родин за межу бідності через непідйомні витрати на потреби тяжкохворої близької людини. Крім того, відсутність гарантій знеболювання, страх болю, соціальна і економічна беззахисність і безпорадність призводять часом до дуже трагічного фіналу - суїциду серед хворих та їхніх родичів [10]. I, навіть, якщо самогубство не відбувається, відчуття безпорадності при спостереженні страждань близької людини, для якої не вдається отримати належну допомогу, часто призводить до важких психоемоційних розладів у членів їх сімей та повної втрати довіри до держави, яка залишає своїх громадян наодинці з їх проблемами саме у найважчий період їх життя.

Вважаємо, що однією з головних причин такої трагічної ситуації в сфері паліативної допомоги в Україні $\epsilon$ відсутність політичної волі до ефективного вирішення цього питання. А політична складова цієї проблеми вже доповнюється недосконалістю законодавчої бази, відсутністю належного фінансування, нерозвиненістю системи хоспісів та виїзних паліативних бригад, а також інформаційним ігноруванням цієї «непопулярної» теми. Внаслідок такої ситуації тисячі громадян нашої країни щодня потерпають від страждань, не отримуючи належної допомоги, а їх близькі зазнають душевних мук, несуть непомірні фінансові витрати та отримують психологічні й психічні розлади. На цьому фоні закономірним є виникнення відчуття глибинної недовіри i, навіть, ненависті до політичної влади власної країни, та, зокрема, до організації системи охорони здоров’я в України. Вважаємо, що такі громадяни вже ніколи не стануть справжніми патріотами держави, що прирікає людей до таких випробувань.

Вважаємо, що паліативна політика України повинна розвиватися в наступних напрямах:

1. система надання паліативної допомоги повинна фактично стати невід'ємною частиною системи охорони здоров'я України, значна частина фінансування якої має відбуватися за рахунок державного бюджету та бути безкоштовною для осіб, що ії потребують; 
2. держава повинна прикладати цілеспрямованих та свідомих зусиль для вивчення та популяризації теми паліативної допомоги та створення діючої системи надання паліативної допомоги інкурабельним хворим, включаючи хворих на злоякісні новоутворення, ішемічну хворобу серця, порушення мозкового кровообігу, хронічні обструктивні захворювання легень, печінкову і ниркову недостатність у фінальних стадіях прогресування, інфекційні захворювання, деменцію тощо;

3. при розробці та реалізації заходів паліативної політики необхідно диференціювати особливості надання допомоги групам пацієнтів з важкими хронічними захворюваннями, які перебувають в різних умовах: вдома, в установах по догляду за людьми похилого віку, в дорослих та дитячих хоспісах, а також у лікарнях, включаючи відділення інтенсивної терапії;

4. в реалізації паліативної політики держави важливо враховувати роль близьких та передбачати надання їм всебічної допомоги у догляді за хворим, які можуть бути багато в чому аналогічними допомозі, що надається в зв'язку з народженням дитини та доглядом за нею;

5. головним напрямом розвитку паліативної політики держави вважаємо створення та розвиток системи хоспісів - спеціалізованих закладів, що функціонують в стаціонарній, амбулаторній та виїзній формах, 3 метою надання комплексної кваліфікованої допомоги в полегшенні болю та страждань інкурабельних хворих та надання всебічної підтримки його близьким.

6. при організації системи паліативної допомоги в Україні варто звертатися до досвіду держав-лідерів в цій сфері, наприклад, тих, що мають найвищі показники за The Quality of Death Index (Великобританія, Австралія, Нова Зеландія, Ірландія, Бельгія тощо).

Висновки. Паліативна допомога - це право людини на гідність в кінці життя. Гідність, що включає відсутність страху, болі та самотності, право на гідне закінчення свого життєвого шляху. Головним завданням паліативної допомоги є підтримка та поліпшення загального самопочуття хворого, що перебуває в термінальній стадії захворювання. Така допомога грунтується на повазі до неповторних індивідуальних особливостей кожної людини, яка має власну унікальну історію, соціальне оточення та культурі. Ця повага, зокрема, проявляється в наданні найкращої та найсучаснішою медичної допомоги, щоб дати людям кращі шанси на повноцінне життя.

Перспективи подальшого дослідження. У зв'язку з тією гостротою, яку мають питання організації паліативної допомоги в Україні, перед дослідниками відкривається широке прикладне коло для реалізації власних наукових інтересів в цій сфері. Стан реалізації паліативної політики України є недостатнім, а наукове дослідження цього питання є таким, що потребує подальших наукових розвідок. Поряд з іншим, вважаємо перспективним подальше вивчення вдалого досвіду та особливостей реалізації паліативної політики держав світу; а також вивчення того впливу, що здійснює якісна паліативно-хоспісна допомога громадянам певної країни на політичну сферу цієї держави, зокрема, в контексті зростання суб'єктивного відчуття захищеності у їі громадян та, як наслідок, збільшення ступеню політичної стабільності такої країни.

\section{Бібліографічний список:}

1. 2015 Quality of Death Index. URL: https://eiuperspectives.economist.com/healthcare/2015-quality-death-index (дата звернення: 08.11.2019).

2. Аймедов К. В., Друзь О. В., Кривоногова О. В. Паліативна та хоспісна допомога. Одеса: Астропринт, 2015. $104 \mathrm{c}$.

3. Всемирная организация здравоохранения. Паллиативная помощь 2005. URL: http://www.euro.who.int/_data/assets/pdf_file/0004/98419/E82931R.pdf (дата звернення: 07.11.2019).

4. Конституція України № 254к/96-ВР від 28.06.1996. URL: https://zakon.rada.gov.ua/laws/main/254к/96-вр (дата звернення: 08.11.2019).

5. Наказ Міністерства соціальної політики України № 58 від 29.01.2016 Про затвердження Державного стандарту паліативного догляду. URL: https://zakon.rada.gov.ua/laws/show/z0247-16 (дата звернення: 08.11.2019).

6. Наказ МО3 України№41 від 21.01.2013 p. Про організацію паліативної допомоги в Україні. URL: https://zakon.rada.gov.ua/laws/show/z0229-13 (дата звернення: 08.11.2019).

7. Основи законодавства України про охорону здоров'я № $2801-$ ХII URL: https://zakon.rada.gov.ua/laws/show/2801-12 (дата звернення: 08.11.2019).

8. Паліативна допомога для полегшення страждань. URL: https://khm.gov.ua/en/node/8279 (дата звернення: 08.11.2019)

9. Спільний Наказ Міністерства соціальної політики та Міністерства охорони здоров’я України № $317 / 353$ від 23.05.2014 р. Про затвердження Порядку взаємодії суб'єктів при наданні соціальних послуг паліативного догляду вдома невиліковно хворим. URL: https://zakon.rada.gov.ua/laws/show/z0625-14 (дата звернення: 08.11.2019).

10. Хвиля самогубств онкохворих накриває країну: MO3 лише розводить руками (відео). Надзвичайні новини. URL: https://nnovosti.info/articles/hvilja_samogubstv_onkohvorih_nakrivaje_krajinu_moz_lishe_rozvodit_ rukami_video-561.html (дата звернення: 08.11.2019).

\section{References:}

1. 2015 Quality of Death Index. URL: https://eiuperspectives.economist.com/healthcare/2015-quality-death-index (data zvernennya: 08.11.2019). $104 \mathrm{~s}$.

2. Aymedov K. V., Druz O. V., Kryvonohova O. V. Paliatyvna ta khospisna dopomoha. Odesa: Astroprynt, 2015.

3. Vsemirnaya organizatsiya zdravookhraneniya. Palliativnaya pomoshch

2005. URL: http://www.euro.who.int/_data/assets/pdf_file/0004/98419/E82931R.pdf (data zvernennya: 07.11.2019). 
4. Konstytutsiya Ukrayiny № 254k/96-VR vid 28.06.1996URL: https://zakon.rada.gov.ua/laws/main/254к/96-вр (data zvernennya: 08.11.2019).

5. Nakaz Ministerstva sotsial'noyi polityky Ukrayiny № 58 vid 29.01.2016 Pro zatverdzhennya Derzhavnoho standartu paliatyvnoho dohlyadu. URL: https://zakon.rada.gov.ua/laws/show/z0247-16 (data zvernennya: 08.11.2019).

6. Nakaz MOZ Ukrayiny№41 vid 21.01.2013 r. Pro orhanizatsiyu paliatyvnoyi dopomohy v Ukrayini. URL: https://zakon.rada.gov.ua/laws/show/z0229-13 (data zvernennya: 08.11.2019).

7. Osnovy zakonodavstva Ukrayiny pro okhoronu zdorov'ya № 2801-XII vid 19.11.1992. URL: https://zakon.rada.gov.ua/laws/show/2801-12 (data zvernennya: 08.11.2019).

8. Paliatyvna dopomoha dlya polehshennya strazhdan. URL: https://khm.gov.ua/en/node/8279 (data zvernennya: 08.11.2019).

9. Spilnyy Nakaz Ministerstva sotsialnoyi polityky ta Ministerstva okhorony zdorovya Ukrayiny № 317/353 vid 23.05.2014 r. Pro zatverdzhennya Poryadku vzayemodiyi subyektiv pry nadanni sotsialnykh posluh paliatyvnoho dohlyadu vdoma nevylikovno khvorym. URL: https://zakon.rada.gov.ua/laws/show/z0625-14 (data zvernennya: 08.11.2019)

10. Khvylya samohubstv onkokhvorykh nakryvaye krayinu: MOZ lyshe rozvodyt rukamy (video). Nadzvychayni novyny. URL: https://nnovosti.info/articles/hvilja_samogubstv_onkohvorih_nakrivaje_krajinu_moz_lishe_rozvodit_rukami_ video-561.html (data zvernennya: 08.11.2019). 